\title{
The Economic Dimension in Great Countries Strategies towards Asia-Pacific Region
}

\author{
Mahmoud Ismial $^{1} \&$ Omar Hamid Shukur $^{2}$ \\ ${ }^{1}$ Faculty of Economic and Political Science, Cairo University, Egypt \\ Correspondence: Omar Hamid Shukur, Faculty of Economic and Political Science, Cairo University, Egypt. \\ E-mail: umar_h_c@yahoo.com
}

Received: June 16, 2016

doi:10.5539/ass.v12n9p107
Accepted: June 30, $2016 \quad$ Online Published: August 26, 2016

URL: http://dx.doi.org/10.5539/ass.v12n9p107

\begin{abstract}
America's and Great Countries economic policy makers have some of the hardest and most important jobs in the world. The economy has become a top priority for countries both capitalism communism and socialism. States are planning short and long-term economic strategy seeking to obtain economic benefits by searching for opportunities and places to bring them to grow and prosper.
\end{abstract}

\section{Introduction}

Asia-Pacific region enjoys a strategic and geo- strategic importance because Asia is the largest continent on the planet, the number of its population is 3.8 billion, is composed of wide ethnical and cultural groups, historical relations, and multiple governmental systems, in addition to the environmental diversity. The Pacific Ocean, also, is the largest ocean. It connects the Asia continent from the Eastern side. Some Eastern Asia Countries Overlook it. It is the waterway that connects the continent of Asia with the continent of North America, South America and Australia. This region mainly include Japan, China, Australia, New Zealand, Taiwan, South Korea, Hong Kong, Singapore and the founding members of the Association of South- East Asia (Malaysia, Indonesia, Thailand, Philippines), also, extends to the United States, some provinces of Canada and small scattered islands in the region.

The Pacific is the main contributor to the global economy, especially countries overlooking it. It provides low cost shipping between East and West, Vast regions for fishing, and the fields of oil, gas and minerals.

One of the most important blocs in the region is Asia- Pacific Economic Cooperation (APEC). It includes 21 countries overlooking the pacific Ocean where about 2.8 billion live there, which represents about $40.5 \%$ of the world's population, and nearly 57\% of World Gross Domestic Product (GDP), and about 49\% of world trade in 2014.

This Article deals with the economic dimension in the strategies of the great powers towards the Asia- pacific region and focuses on the United States, Russia and China.

\section{The American Strategy towards Asia-Pacific Region}

In 2012, Barak Obama, the American President, announced the new American strategy of Asia- pacific region. It is a part of the strategic plan that he submitted to the Defense Ministry aiming to rebalance to Asia- Pacific region. Some argue that this region overshadowed by imbalances of power where the Chinese economic and military growth made the United States interested in the region and giving it a strategic priority. In the past, priority was given to the Middle East. Europe occupied the first place in the American strategy during the Cold War, fearing of extending the previous Soviet Union. It is noted that the United States reordered its strategic priorities. This transformation stems from the changing economic, political and military map in the world.

Hillary Clinton, Ex Us secretary of state wrote in "Foreign Policy" Magazine5: "Asia- Pacific region which stretches from the Indian subcontinent to the Western shores of the Americas, and arrives to the two pacific and Indian oceans, has become the major engine of global politics. This region is important due to the ways of the strategic shipping, comprises energy half of the world's population, includes many of the main engines of the global economy, includes a great deal of the emitters of gases causing greenhouse, and it is home to a number of key allies of Washington and home to emerging powers like China, India and Indonesia". 
The secretary of state showed that the US administration aims, through its foreign policy towards Asia- Pacific region to:

1. Enhancing the bilateral security alliances.

2. Deepening relations with emerging powers, including china.

3. Dealing with multilateral regional institutions.

4. Expanding trade and investment.

5. Increasing the extensive military presence.

6. Promotion of democracy and human rights.

One of the most important pillars of the American strategy is: rebalancing in Asia-pacific region by projecting power. The pentagon plans to put $60 \%$ of US navy in the pacific by 2020 . Also, the American department of defense was keen to maintain and promote investment in the new required assets and most desired in the pacific ocean.

\subsection{The Economic Objective}

Most American efforts aiming to rebalancing are concentrated on non-military areas such as trade and development. President Barak Obama asserted on this matter through deepening diplomatic, developmental, economic, security and cultural relations in the entire region. From the perspective of the department of defense, rebalancing aims to ensuring the continuation of the United States and all countries in the region in benefiting from the prosperity of Asia-pacific region as it was during seventy years.

The United States seeks to not allow to any country in Asia to dominate the resources of the continent where China qualified to this matter. Therefore, Washington established its strategy to contain the Asian giant by strengthening military ties and building alliances with new partners.

The economic relationship is the cornerstone of the overall US- China relations during the past thirty years. Since China adopted reform and open policy, economic interdependence between Washington and Beijing dramatically rose. In 2013, the volume of the trade exchange between the two countries amounted to $\$ 520$ billion. The bulk of the direct American investment in the Chinese stock market amounted to between $\$ 50$ and 70 billion. In 2013, the bulk of the Chinese investments in the American stock market \$ 17 billion.

Some suggest that the rise of China enhanced Washington's position and expanded its security arrangements in Asia. South Korea strengthen its military alliance with the United States. Japan retreated from its demands concerning the transfer of US Marine base out Okinawa Island. In addition to India, Vietnam, Indonesia and the Philippines became satellite states of the United States. However, the Chinese factor remains assistant factor as long as America's partners see that it is a credible guarantor of security and stability, a task that does not require a military force, but a political will in Washington.

"The strategy adopted by the Obama administration aimed at rebalancing in Asia was useful for all countries on both sides of the pacific, according to scot Marciel, deputy assistant secretary of state's office that is responsible for East Asia and pacific affairs". He added: "the current progress in this area become apparent. For example, the volume of trade between the United States and East Asia and the pacific rose by $22 \%$ between the years 2008 and 2012, exceeding the rate of growth in the American global trade amounting to 13\%. Also the United States is the first foreign investor in East Asia and the Pacific where the total foreign direct investments of the United States amounted to $\$ 622$ billion in 2012, with a rise amounted to $35 \%$ from 2008 . Furthermore, the investments of the East Asia and the pacific in the United States substantially increased which amounted to $31 \%$ since 2008 to reach $\$ 422$ billion at the end of 2012 .

The United States is seeking to ensure the success of the trans- Pacific Partnership which is a free trade agreement project aimed at deepening the economic ties between 12 countries (Australia, Brunei, Darussalam, Canada, chili, Malaysia, Mexico, New Zealand, Peru, the united states, Singapore, Vietnam and Japan). It is expected that the agreement will reduce tariffs volume significantly between member states, and even get rid of them in some cases. It will open other areas in goods and services trade. It will support investment flows between these countries and increase its economic growth. Furthermore, the agreement's member states will seek to enhance a strong relationship for the economic policies and regulatory issues. US president Barak Obama said after reaching the agreement: "when more than $95 \%$ of our potential consumers live outside our borders, it could not make countries like china dominant on the rules of the global economy. He added: we should write these rules, open new markets for the American products and establish high standards for protecting our worker as well as maintaining our environment". 
Some analysts believe that the United States resorts to such partnership in an attempt to undermine the economic power of China in the region. Many also believe that the reset of the member of APEC may joint this agreement in the coming years that could increase its importance. The number of consumers of these countries that participate in trans-pacific partnership agreement amounted to 800 million people, and the product of the twelve countries amounted to $\$ 28$. Trillion, equivalent to $40 \%$ of global gross product.

And come US President Barack Obama's strategy to restore balance in the Asia-Pacific region, with the escalating controversy of the US regarding the future of the United States in three main streams; first is that China's power in the growing, and it is ongoing to overtake the US as well as to replace them in the leadership system international, and that this century will be the "Chinese century". Second: that the United States will remaining the dominant global force although of the rise of other international forces in the forefront of China, and that the atheist and the twentieth century is the "American Century" par excellence. The third is that the international system would tend to a state of "non-polar", where to miss the concentration of specific powers in the international system, with the increasing roles of actors at the international level.

Proponents of the survival of the United States unipolar globally despite the rise of China economically and militarily, where this power is the most popular among American writers and analysts. One of his supporters, "Joseph Nye", who is stated in his new book (Is the American century over), that the Chinese economic power in growing compared to US economic power on the basis of purchasing power, but this does not mean superiority of Chinese power on their American counterparts in the overall image.

To illustrate differentiate "nay" between the concepts of "absolute decline" and "relative decline", to the fact that the concept of "decline" in itself understandable misleading and confusing. It is intended "nay" to "absolute decline" when the dominant forces face internal obstacles to enable other forces of the rival to beat. The "relative decline" when it is intended to maintain superpower strong against "the rise of other international powers," but without that first crossed.

Based on the distinction between the concepts of retreat, "Nye" believes that American power is in relative decline and not absolute; a decline in some aspects of US power, especially economic power with the decline in the US contribution to global production ratio, which was at the beginning of the twentieth century quarter, then rose to half in the middle of the century, to return again to the quarter end, it is expected that this percentage drops in the coming years. "Nye" This is a relative decrease, not at all, because the successes and high levels of contribution made by the emerging powers in the global economy are caused by policies adopted by the United States after World War II, and established an international system and economic benefited from these emerging powers, and the United States to reverse the rising powers have the ability to act internationally, and the formulation of international policies and the formation of alliances and coalitions.

To emphasize that the United States will continue to retain its status and its lead of the international system, speaks of "Joseph Nye", and his supporter's survival of the United States for three basic components of a US force:

First: economic power: the United States continues to enjoy economic strength despite expectations outweigh the Chinese economy on the US counterpart, as the central role of the dollar in the global economy, as the most reliable currency in the cash reserves of the various countries of the world, which is unmatched by any other currency, and that the share of American per capita income four times the share of China's per capita income, as well as the founding of the American economy on the technology, development and innovation, which gives it an advantage not available to his Chinese counterpart.

Second: military force: Although China's growing military spending and the growing Chinese military capabilities, but China ranks second after the United States in military spending. In 2014 the US military budget amounted to about 581 billion dollars, compared with 129.4 billion dollars to China.

Third: soft power: the united States overtake China in soft power, despite the billions of dollars spent on the Beijing soft power. This is due, "Nye" the failure of the Chinese soft power for two main reasons; First: the control of the official Chinese institutions on soft power initiatives, while undermining the chances of informal institutions that are the basis for the efficacy country's soft power. The second relates to the territorial disputes with neighboring countries, such as Japan, Vietnam, the Philippines, India; which generates difficulties for Chinese attempts to attract the citizens of those countries to support the interests of the Chinese and values.

\section{The Russian Strategy toward Asia-Pacific Region}

Since taking office in January 2000, President Vladimir Putin sought to deepen the Eurasian orientation in Russia's foreign policy. He presented several principles known as Putin's principle. It was based on: 
First: establishing its position as an independent force in a multi polar world. The primary focus was to maintain its preeminent position in the former soviet republics.

Second: restoring Russia's role in Asia and the Middle East gradually, and not allowing the west to marginalize Russia's role in international relations.

Third: developing the Russian economy. In Russian foreign policy's document in 2000, the independent commonwealth states, that were a part of the soviet union, has been put on the forefront of the priorities of Russian foreign policy, then Europe, the united states, Asia (respectively china, India, South Asia, Japan, southeast Asia, Iran, Korean peninsula and Afghanistan), the Middle East, Africa, and then central and south America. Russia is seeking to build its strategy in order to occupy a privileged position in a multi-polar world where the Russian foreign policy emphasizes that the problems facing the world from wars and crises is due to a uni- polar world on which the united states dominates. Russia joined to Asia -pacific economic cooperation (APEC) in1998. Dmitry Medvedev, prime minister of Russia, stressed that the development of cooperation with the countries of Asia-pacific region is a key strategic goal for Russia, and does not depend on the international political situation. During the summit of Asia-pacific economic cooperation (APEC) in the capital of Philippines, Manila, which was launched on Wednesday, November 18, 2015, prime minister Dmitry Medvedev said: "such APEC summit enhances our cooperation in all sectors. This approach is consistent with our policy in Asia-pacific region".

Russia confirmed its participation in the structures of the main integration of Asia-pacific region (ASEAN), and the mechanisms of partnership with Southeast Asia countries, including the regional ASEAN forum. ASEAN countries are Indonesia, Malaysia, the Philippines, Singapore, Thailand, Brunei, Vietnam, Laos, Burma and Cambodia. Moscow plans, through Vietnam which is Russia's gateway to the ASEAN's markets, to strengthen its presence in the Asian markets. Russia ranked fourteenth among the partners of ASEAN where the volume the trade exchange between Russia and this Association amounted to \$22.5 billion in 2014.

Russia's foreign policy interests in Shanghai region and support its initiatives to establish partnership links between all integrative organizations in Asia- Pacific. Russia puts China on the list of its priorities. President Vladimir Putin said: "it is located, next to our country, an important center for the global economy which is China". He added in his article titled: "Russian Voltaire Network that" it has become fashionable to talk about China's the future role in the global economy and international affairs. In the past years, China occupied the second rank globally concerning the gross domestic product (GDP). According to the international experts, including the American ones, China will surpass the United States in this indicator. Also, China's total power will increase. Including the extending of its power in different areas".

According to the numbers of September 2015, Russia has become the largest exporter of oil to China, exceeding Saudi Arabia which is the largest producer of OPEC organization. Chinese customs data showed that Beijing bought 4.042 million tons of crude oil from Russia, the equivalent of about one million barrels per day, more increasing by $42 \%$ than the same period of the past year. Furthermore, Russia and China reached an agreement after a decade of negotiations, which ensures exporting natural gas to China. This agreement extends for a period of 30 years and amounts to $\$ 400$ billion.

As for Russia's policy towards India, Moscow confirms that the relationship with India is important where it is an important country in light of the rapid economic growth, which is considered the second economy after China in terms of growth. According to 2015 figures, the average of mutual investments between Russia and India amounted to around $\$ 11$ billion. Also, the two countries plan to increase this average from 30 to 50 billion by 2025.

In 2014, the volume of the trade exchange between them less than 10 billion dollars, and they are planning to increase it to $\$ 30$ billion over the next ten years.

Russia increased its interest in Asia- pacific region. Therefore, the Russian foreign policy's document in 2012 confirmed that this region is put on the tope of Russia's agenda, and it is seeking to be the link between Europe and Asia pacific region.

Russia contributes to the stability of the food supply in Asia- pacific countries where it plans to produce 120-125 million tons of grain by 2020. In 2014, Russia's grain returns were $\$ 20$ billion.

In 2009, Russia inaugurated oil pipeline network in Eastern Siberia, the Pacific Ocean, in Kozmino port located in the far east of Russia. Putin emphasized that this strategic project will provide access to new markets in AsiaPacific region and it will give impetus to the development of the region and the diversity of the routes of crude oil export. He said that the project has been accomplished in five years, and the cost of the first phase amounts to 
$\$ 12$ billion, in addition to spending about two billion dollars for constructing the port of marine Kozmino.

In an effort to strengthen Russia's ties with the central Asian countries, it was keen to build institutional strategic partnership with China in the framework of the Shanghai Cooperation Organization, which includes Central Asia countries except Turkmenistan.

Russia sougth to be the link between Asia and Europe. Therefore, it established the Eurasian Economic Community on 10 October 2000, which includes Russia, Belarus, Kazakhstan, Tajikistan, Uzbekistan and Kyrgyzstan. General Secretariat is located in Moscow.

Economic benefits through the export of Russian arms to Asia:

Asian countries ranked as the largest import market for the Russian arms. Therefore, the importance of Asia emerged as a salable market for Russian weapons. In its strategic planning to increase Russian weapons exports, the Russian government focused on expanding the marketing of weapons to the possible maximum geographic extent that helped raise the number of countries buying Russian weapons to about 70 countries. China and India comes in the forefront of these countries.

In the framework of the traditional competition on the global front in the field of arms exports, Russia succeeded in occupying the first place in the export of conventional weapons during the period from 2000 to 2004. The value of the weapons concluded by Russia during that period amounted to $\$ 26.9$ billion, with percentage of $31.87 \%$ from the global total. Thus, it surpassed the United States and all other suppliers.

The main factor behind the rise in the value of Russia arms exports is huge arms purchases contracted by China and India with Russia where low prices and providing buyers with relatively sophisticated military technology not offered by other major countries contributed to the completion of these huge deals. According to Stockholm Institute for peace Research, the first largest suppliers of traditional weapons during the period from 2008 to 2012 are: the United States (30\% of global arms exports), Russia (26\%), Germany (7\%), France (6\%) and China $(5 \%)$.

\section{The Chinese Strategy towards Asia-Pacific Region}

Traditionally, China is one of the influential major powers in Asia-Pacific region, in addition to the United States, Russia and Japan. Historically, Asia, particularly Southeast Asia, is China's influence area. The nature of this influence does not change, but we can say that it began to take a new face in the shadow China's rise. China puts economy in the front of its priorities in order to achieve compatibility between its geo-economic strategy and its internal needs. This matter was clear through the trade exchange rates. In 2007, the bulk of trade between China and ASEAN countries amounted to $\$ 202.6$ billion, by $25.9 \%$ increase annually.

The volume of the bilateral trade between China and ASEAN countries amounted to $\$ 136.48$ billion in the first half of 2010, which saw increase of $54.7 \%$ compared to the same period of the last year. China's exports to ASEAN countries amounted to $\$ 64.6$ billion, and its imports from ASEAN countries reached $\$ 71.89$ billion. ASEAN has become the third largest trading partner of China currently, rather than Japan.

According to statistics issued from the Chinese side, the value of the bilateral trade between China and ASEAN countries increased from $\$ 54.77$ billion in 2002 to $\$ 400.1$ billion in 2012 , with increase of $22 \%$ annually.

China provided economic aids for the Asian countries affected by the 1997 crisis. Therefore it was qualified to act as a leader in Asia region, and enhanced its agreement with ASEAN countries concerning establishing a joint free trade zone, which is established on January 1, 2010. Thus, about 7000 kind of products became exempt from customs duties within the region.

The value of China's direct investment in ASEAN countries increased from $\$ 0.23$ billion in 2003 to $\$ 2.18$ billion in 2008, which achieved an increase of nearly 9 times. The total of the bilateral investments between China and ASEAN countries amounted to about \$ 70 billion until April 2009.

In the field of the foreign direct investments, ASEAN region registered a dramatic number which is $\$ 125.4$ billion dollars. Therefore, it occupied the second category globally after the United States, which in turn attracted investments amounted to $\$ 187.5$ billion.

On the other hand, the volume of foreign direct investment flows to China reached $\$ 129$ billion in 2014, which was estimated at $4 \%$. This is due to increasing foreign direct investment in services sector, while foreign direct investment in the field of the transformational industry declined, especially industries affected speedily by the high cost of labor. The flows to Hong Kong (China) increased by $39 \%$, and then the volume of flows was $\$ 103$ billion. 
As for trade between China and India has increased from $\$ 29$ billion in 2000 to $\$ 51.78$ billion in 2008, by $43 \%$ annually. Despite the global financial crisis in 2008, the trade between the two countries is still a relatively high level where it was amounted to about $\$ 44.38$ billion in 2009 and about $\$ 60$ billion in 2010 .

According to a report, the Chinese investment in India totaled \$ 250 million in 2010. There are more than 60 Chinese companies were exercising the works of development and entrepreneurship in India.

Concerning the economic relations with Russia, the sources of energy enjoy a great importance, especially Russia's energy exports to China continue to increase where China turned into a profitable market for Russian oil.

Russia occupied the first category for oil exports to the Chinese markets in 2015, where China imported 1.04 million barrels of Russian oil per day. It is said that Saudi Arabia occupied the first place in the export of oil to China in the past.

The bilateral trade between the two countries reached about one hundred billion dollars in 2013. "China and Russia aim to increase the bulk of trade between them to reach two hundred billion dollars in 2020" according to Russian prime minister Dmitry Medvedev.

China exceeded Japan in exports to Asian markets in 2004, after three years from joining to World Trade Organization (WTO). China surpassed the United States in 2007, and transcended Germany in 2009 to become the largest exporter globally. According to the numbers of 2014, China occupied the first place in the exports rate globally.

China follows a cautious strategy that some researchers called a calculated strategy, aiming at protecting China from external threats as its economic rise and powerful elements continue. China sought to avoid collision directly with the regional forces, or at least putting a limit of this clash, including any possible clash with Taiwan.

China declares, through its statements issued by the Ministry of Foreign Affairs and international forums, that it adopts a peaceful policy in its path of development and economic, political and security rising. Also, it emphasizes on a well neighborhood policy with its neighbors and its commitment to the development of its regional and international relations.

It can be said that the Sino-Russian interests converge on a number of points where they come in the front of their joint agendas permanently, and have been repeated and emphasized at every appropriate opportunity. These points are: First, the two sides are willing to strengthen their power against the United States. Second, both countries always announce their support for the idea of a multi polar world. Third, both parties are very worried about the issue of instability and are ready to resort to authoritarian measures internally and externally in order to stabilize their power. At the domestic level, both of them face the problem of dealing with minorities. On the external front, both sides refuse the external intervention in Central Asia, and both fear the fall of this region under the Western influence. Fourth, both sides refuse the American missile defense umbrella, and fear of the spread of weapons of mass destruction and use these weapons against them, either through other countries or groups.

\section{The Chinese Strategy towards the Central Asia Region}

China's the strategic vision is centered in the initiative of the new silk road of the twenty-first century. This matter was affirmed by the Chinese president "Hu" during his visit to Kazakhstan in October 2013 where he said that this road and the economic belt surrounding it would crest commercial corridors linking East and Southeast Asia with the rest of Asia, Europe, Middle East and Africa. Therefore, China's vision is seeking to achieve the integration of Central Asia with the rest of Asia and the other regions of the world associated with it. This vision includes transport by rail, land, air lines and marine pipelines. China provides $\$ 40$ billion for this initiative, in addition to manageable financing of new institutions such as the Asian Development Bank for the development of infrastructure and the New Development Bank. China plays a leadership position in both banks.

This initiative achieves many benefits, which are: the promotion of the economic development, increasing the Chinese exports to Central Asia, expanding and increasing the land transport allowing China to diversify their import and export channels, defuse the danger of the sea lanes that are still controlled by the United States, and investment in the new infrastructure consolidates the Chinese economic and political influence. It is noticeable that China focus, in the first phase, on the economic side, hoping that developments will pave the way of the Chinese leadership towards the Asian security cooperation.

It seems that China has three goals and wise-ranging in the Caspian Sea region, which is related to its interests in 
Central Asia. It is estimated that the Caspian Sea is home to the largest reserves of oil and natural gas in the world after the Persian Gulf and Russia. These objectives are:

1. Providing security to the region and establishing stability in Xinjiang province.

2. Access to natural resources.

3. Consolidating the political influence in order to be a regional dominance through the political framework for "Shanghai Cooperation Organization"

This is a part of the components of the Silk Road followed by China to diversify its energy dependence away from the unstable Gulf region and building ground paths to avoid the obstacles of the naval supply from the Gulf.46China enhanced, also, its ability to extract the energy resources from the region through establishing the oil pipeline from Kazakhstan (completed in 2006), and the pipeline of the liquefied natural gas from Turkmenistan (completed in 2009).

China has intensified, over the past few years, its investments in Central Asia and Caspian Sea, particularly Kazakhstan and Turkmenistan through the two main projects of infrastructure, which are: Kazakhstan-China oil pipeline (has been achieved in 2006), and Turkmenistan-China gas pipeline, also known as Central Asia-China gas pipeline (has been achieved in 2009).

According to China's National Defense document issued in 2010 concerning Asia-Pacific region:" China is seeking to enhance the economic development and the stability of the region through the bilateral and multilateral cooperation with ASEAN organization in addition to Japan, China and South Korea, Shanghai Organization, and Asia-Pacific Economic Cooperation (APEC) forum. However, the document warned that the situation has become more complex and volatile where there is an intermittent tension in the Korean Peninsula. Furthermore, the security situation in Afghanistan remains serious, the political unrests in some countries are still continuing, the ethnic and religious disagreement is evident as in the Philippines, Myanmar and Thailand, The issues of terrorism and extremism, and the border disputes. The document added that China faces great pressures in maintaining the maritime rights and interests. It referred that there are profound changes in the strategic landscape of the great powers in Asia-Pacific region. For example, promoting the regional military alliances and increasing the participation in the regional and security issues by the United States. Also, the Chinese growing concern appeared in the efforts of the United States to contain China.

\section{Conclusion}

It is clear through the previous presentation that the economic dimension was evident in the United States, Russia and China's strategies towards Asia-Pacific region. Every party pursuits extending and promoting its influence, in the sense that strengthening the American presence came with the growing rise of China's economic and military power, and that Russia is seeking to enhance its existence in the region to curb the American influence in the region, and benefits from the rising economic growth, which feeds the Russian economy. China is seeking to curb the American influence, bolster its economy and maritime influence and reassure its neighbors that its seeking to dominate the region does not mean dominance in itself, but means leadership, especially it has the elements of leadership by its growing economy and military power. However, we see that the United States and China came on the top of the situation in this important region, especially the economic aspect.

Accordingly, the two prominent powers in Asia-Pacific region are the United States and China, and both of them is trying to limit the influence of the other for economic gains.

\section{References}

Ahmed, I. M. (2007). The Russian Military Industries: Strengthening the Economy and International Status. Al-Siyassa Al-Dawliya Journal, 42.

Ali, S. N. (2009). China's foreign policy and its Relations with the United States. Cairo: the Egyptian Book Authority, 95.

Alice, D. B. (2003). China and ASEAN: Renavigating Relations for a $21^{\text {st }}$ Century Asia. Asian Survey, 43(4), 634-639.

Andrew, M. (2013). The New Russian Foreign Policy Concept: Evolving Continuity. Chatham House, London.

Andrew, S., Ely, R., \& Michael, B. (2014). China's Strategy toward South and Central Asia.

Brahma, C. (2012). The New US Strategy in Asia: Features and Challenges. Al Jazeera Center for Studies reports. Retrieved from http://studies.aljazeera.net/reports/2012/02/2012219114838206874.htm

Chien, P. C. (2009, March). "The Good Neighbor Policy" in the context of china's foreign relations. China: An 
international Journal.

Christina, Y. L. (2010, August). The Caspian Sea: China's Silk Road Strategy Converges with Damascus. The Washington Institute, 10(17). Retrieved from http://www.washingtoninstitute.org/uploads/Documents/ opeds/4c6ea2bc9cb97.pdf

DmItry, G. (2011). New Directions in Russian Foreign Policy. Retrieved from https://russiamil.wordpress.com/ 2011/11/14/new-directions-in-russian-foreign-policy-editor\%E2\%80\%99s-introduction/

Edward, K. (1970). The Cold War between Moscow and Beijing, translated by Translation Committee in the Commercial center, Beirut, Lebanon.

Hillary, C. (2011, October). America's Pacific Century. Retrieved from http://archive.defense.gov/news/ Defense_Strategic_Guidance.pdf

https://www.chathamhouse.org/sites/files/chathamhouse/public/Research/Russia\%20and\%20Eurasia/0413pp_mo naghan.pdf

Jane, M. (2013, December). Obama's Rebalancing in Asia Is Win-Win Strategy. Retrieved from http://iipdigital.usembassy.gov/st/english/article/2013/12/20131219289256.html\#axzz4F633xmCf

Joseph, N. (2015). Is the American Century Over? Policy Press, USA.

Leon, P. (2012, December). America's Pacific Rebalance. Project Syndicate the world opinion page. Retrieved from https://www.project-syndicate.org/commentary/renewing-the-us-commitment-to-the-asia-pacificregion-by-leon-e--panetta?barrier=true

Mohamed, S. S. (2011, January). The Reality and the Future of Alliances in Asia. Al-Siyassa aal-Dawliya Journal, A-ahram Center for Political and Strategic Studies, Cairo, Egypt.

Ria, K. (2016). Central Asia in the Conflict of the Great Powers. The National Center for Reseach and Public Opinion. Retrieved from http://ncro.sy/?p=3057

Richard, N. H. (2008, May). The Age of Nonpolarity: What Will Follow US Dominance. Foreign Affairs.

Russia substitutes Saudi Arabia as the largest oil exporter to China. (2015, May). Al-Sharq Al-Aesat newspaper.

The future of politics will be decided in Asia, not Afghanistan or Iraq, and the United States will be right at the center of the action. Foreign Policy. Retrieved from http://foreignpolicy.com/2011/10/11/americaspacific-century/

Vladimir, P. (2000, June). The Foreign Policy Concept of the Russian Federation. Retrieved from http://fas.org/nuke/guide/russia/doctrine/econcept.htm

Vladimir, P. (2007, February). Mono-pole rule against the law and morality. Retrieved from http://www.voltairenet.org/article145391.html

Vladimir, P. (2012, February). Russia and the Changing World. Voltaire Network. Retrieved from http://www.voltairenet.org/article173054.html

World military spending falls, but China, Russia's spending rises, says SIPRI. (2013, April 15). Retrieved from https://www.sipri.org/media/press-release/2013/world-military-spending-falls-china-russias-spending-risessays-sipri

\section{Copyrights}

Copyright for this article is retained by the author(s), with first publication rights granted to the journal.

This is an open-access article distributed under the terms and conditions of the Creative Commons Attribution license (http://creativecommons.org/licenses/by/4.0/). 